\title{
Function of milk polymorphonuclear neutrophil leukocytes in bovine mammary glands infected with Corynebacterium bovis
}

\author{
M. G. Blagitz, ${ }^{* 1}$ F. N. Souza, $†$ B. P. Santos, ${ }^{\star}$ C. F. Batista, ${ }^{*}$ A. C. Parra, ${ }^{*}$ L. F. F. Azevedo, ${ }^{*}$ P. A. Melville, $\ddagger$ \\ N. R. Benites, $\ddagger$ and A. M. M. P. Della Libera* \\ *Departamento de Clínica Médica, Faculdade de Medicina Veterinária e Zootecnia, Universidade de São Paulo, Cidade Universitária, \\ São Paulo 05508-270, Brazil \\ †Departamento de Medicina Veterinária Preventiva, Escola de Veterinária, Universidade Federal de Minas Gerais, Belo Horizonte 31270-010, \\ Brazil \\ łDepartamento de Medicina Veterinária Preventiva e Saúde Animal, Faculdade de Medicina Veterinária e Zootecnia, Universidade de São Paulo, \\ São Paulo 05508-270, Brazil
}

\section{ABSTRACT}

Corynebacterium bovis is one of the most commonly isolated bacteria from aseptically collected bovine milk samples. The objective of the current study was to characterize the bovine innate immune response by evaluating milk polymorphonuclear neutrophilic leukocytes (PMNL) in mammary glands infected with $C$. bovis. Twenty quarters infected with $C$. bovis and 28 culture-negative quarters (with milk somatic cell count $<1 \times 10^{5}$ cells $/ \mathrm{mL}$ ) were used. The percentages of milk PMNL and the PMNL expression of L-selectin (CD62L), $\beta_{2}$-integrin (CD11b), and one of the endothelial-selectin ligands (CD44), as well as the levels of intracellular reactive oxygen species (ROS) and the phagocytosis of Staphylococcus aureus, were evaluated by flow cytometry. The apoptosis and necrosis rates of the PMNL were quantified using dual-color flow cytometry with fluorescein-labeled annexin and propidium iodide. The present study revealed a higher percentage of PMNL in the milk from C. bovis-infected quarters, although no significant differences were found in levels of CD44, CD62L, or CD11b expression among the PMNL. A lower percentage of apoptotic PMNL was observed in $C$. bovis-infected quarters, as well as higher percentages of viable PMNL and of PMNL that produced intracellular ROS. However, no alterations were observed in phagocytosis of Staph. aureus by the PMNL or in intensity of intracellular ROS production by PMNL. Thus, results from this investigation of the PMNL function support, at least in part, the fact that intramammary infections by $C$. bovis may offer protection against intramammary infections by other bacteria.

Key words: dairy cow, mammary gland, mastitis milk, polymorphonuclear neutrophil leukocyte

Received November 10, 2012

Accepted March 6, 2013.

${ }^{1}$ Corresponding author: magblagitz@uol.com.br

\section{INTRODUCTION}

Corynebacterium bovis is one of the most commonly isolated bacteria from samples that are submitted for the identification of IMI-causing pathogens around the world (Wilson et al., 1997; Pitkälä et al., 2004; Haltia et al., 2006; Tenhagen et al., 2006; Souza et al., 2009). Despite its high prevalence, C. bovis is regarded as a minor pathogen with limited clinical significance (Huxley et al., 2004) and has previously been regarded as a commensal organism (Brooks and Barnum, 1984). This bacterium colonizes the teat canal region, but it can also be isolated from the teat cistern, gland cistern, and mammary parenchyma (Benites et al., 2003). Furthermore, although the mean milk SCC (MSCC) recorded in milk samples from which $C$. bovis is isolated is relatively low, it is higher than the mean MSCC recorded in samples yielding no growth (Pankey et al., 1985; Wilson et al., 1997; Djabri et al., 2002).

Corynebacterium bovis is of interest to mastitis researchers because of the observation that quarters infected with this bacterium are significantly less likely to become infected with other, more pathogenic bacteria (Brooks and Barnum, 1984; Pankey et al., 1985; Rainard and Poutrel, 1988; Sordillo et al., 1988; Lam et al., 1997; Schukken et al., 1999; Rainard and Riollet, 2003). Several natural biological mechanisms were suggested to explain the enhanced resistance of $C$. bovis-colonized quarters to major pathogens (Brooks and Barnum, 1984; Sordillo et al., 1988). With this in mind, it should be noted that PMNL provide the first cellular line of defense against the invading mastitis pathogens and are the main source of resistance during the early stages of bacterial invasion (Rainard and Riollet, 2003, 2006; Paape et al., 2003; Zhao and Lacasse, 2008; Elazar et al., 2010). In contrast to the studies mentioned above, other work has demonstrated either no protective effect (Rainard and Poutrel, 1982; Brooks et al., 1983; Honkanen-Buzalski et al., 1984; Zadoks et al., 2001; Reyher et al., 2012) or an increased rate of new IMI 
in quarters infected with C. bovis (Pankey et al., 1985; Hogan et al., 1988). Nonetheless, to the best of our knowledge, this is the first study to evaluate the function of milk PMNL in C. bovis-infected quarters.

Thus, the aim of this study was to investigate the function of milk PMNL from healthy mammary glands with low cellularity and from mammary glands naturally infected with $C$. bovis.

\section{MATERIALS AND METHODS}

\section{Animals and Sample Collection}

The present study used 48 mammary quarters from 18 clinically normal Holstein dairy cows, collected at different lactation stages from a commercial herd. From this sample, we selected 28 culture-negative control quarters from 12 dairy cows with no abnormal secretions in the strip cup test and an MSCC $<1 \times 10^{5}$ cells/ $\mathrm{mL}$, as the threshold for MSCC described by Bansal et al. (2005) and Schwarz et al. (2010) in uninfected quarters. Additionally, 20 C. bovis-infected quarters from 10 dairy cows were included.

First, the strip cup test was performed to identify the presence of clots, flakes, or otherwise obviously abnormal secretions. Then, predipping was performed and one towel was used for each teat. After discarding the first 3 milk streams, teat ends were scrubbed with cotton soaked in $70 \%$ ethanol, and single milk samples from individual mammary quarters were aseptically collected into sterile vials for bacteriological analysis. Finally, milk samples for SCC and evaluation of neutrophilic function were collected. Samples were kept at $4^{\circ} \mathrm{C}$ until arriving at the laboratory. Milk samples for bacteriological analysis were refrigerated at $-20^{\circ} \mathrm{C}$ until analysis.

\section{Bacteriological Analysis}

The bacteriological analysis was carried out by culturing $0.01 \mathrm{~mL}$ of each milk quarter sample on $5 \%$ ovine blood agar plates. The plates were incubated for $72 \mathrm{~h}$ at $37^{\circ} \mathrm{C}$, followed by Gram staining, observation of colony morphology, and biochemical testing (Oliver et al., 2004). A milk sample was considered culture-positive when growth of $\geq 4$ pure $C$. bovis colonies was detected. Samples yielding no bacterial growth were regarded as culture-negative.

\section{Determination of SCC}

Milk samples for SCC measurement were collected in $40-\mathrm{mL}$ vials containing microtablets of bronopol (2-bromo-2-nitropane-1,3-diol) as a preserving agent.
Subsequently, the SCC measurements were performed using an automated fluorescent microscopic somatic cell counter (Somacount 300, Bentley Instruments, Chaska, MN).

\section{Separation of Milk Cells}

The separation of milk cells was performed as described by Koess and Hamann (2008). Briefly, 1 L of milk was diluted with $1 \mathrm{~L}$ of PBS $(\mathrm{pH} 7.4,1.06 \mathrm{mM}$ $\left.\mathrm{Na}_{2} \mathrm{HPO}_{4}, 155.17 \mathrm{~m} M \mathrm{NaCl}, 2.97 \mathrm{~m} M \mathrm{Na}_{2} \mathrm{HPO}_{4} \cdot 7 \mathrm{H}_{2} \mathrm{O}\right)$. After centrifugation at $1,000 \times g$ for $15 \mathrm{~min}$, the cream layer and the supernatant were discarded. The cell pellet in the bottom of the container was then washed once with $30 \mathrm{~mL}$ of PBS and centrifuged at $400 \times g$ for 10 min. The cells were then placed in $1 \mathrm{~mL}$ of RPMI-1640 culture medium (R7638, Sigma Aldrich, St. Louis, MO) supplemented with $10 \%$ fetal bovine serum (Cultilab, Campinas, Brazil) and counted in a Neubauer chamber. Cell viability was first evaluated by trypan blue exclusion. The milk cells were then diluted with the culture medium and $10 \%$ fetal bovine serum to a concentration of $2 \times 10^{6}$ viable cells $/ \mathrm{mL}$.

\section{Identification of PMNL}

Milk neutrophils were differentiated from other cells by indirect fluorescent labeling using a primary unlabeled $\mathrm{mAb}$, anti-bovine granulocyte (CH138A, VMRD Pullman Corp., Pullman, WA), that was incubated for $30 \mathrm{~min}$ at room temperature. Then, $1 \mathrm{~mL}$ of PBS was added to the cell suspension and centrifuged at $400 \times g$ for 8 min. Finally, the labeled secondary antibody was added and incubated for $30 \mathrm{~min}$ at room temperature in the dark to visualize the CH138A binding. Neutrophils were identified by flow cytometry based on their cytoplasmic granularity and CH138A positivity (Figure 1 ), as previously described by Piepers et al. (2009). The secondary labeled $\mathrm{mAb}$ were as follows: allophycocyanin (M31505, Invitrogen, Carlsbad, CA), fluorescein isothiocyanate (FITC; M31501, Invitrogen), or phycoerythrin (M31504, Invitrogen) goat anti-mouse IgM antibodies.

\section{Detection of Cell Death by Flow Cytometry}

The death of the PMNL was measured by dual labeling with annexin $\mathrm{V}$ and propidium iodide (PI; K2350, Apoptest-FITC, DakoCytomation, Mijdrecht, the Netherlands) and flow cytometric analysis, as previously described by Piepers et al. (2009). Briefly, $2 \times 10^{5}$ viable milk cells were suspended in $100 \mu \mathrm{L}$ of binding buffer (10 mM HEPES, $150 \mathrm{mM} \mathrm{NaCl}, 1 \mathrm{~m} M \mathrm{MgCl}_{2}$, and $1.8 \mathrm{mM} \mathrm{CaCl}_{2}$ ) containing annexin V-FITC and 

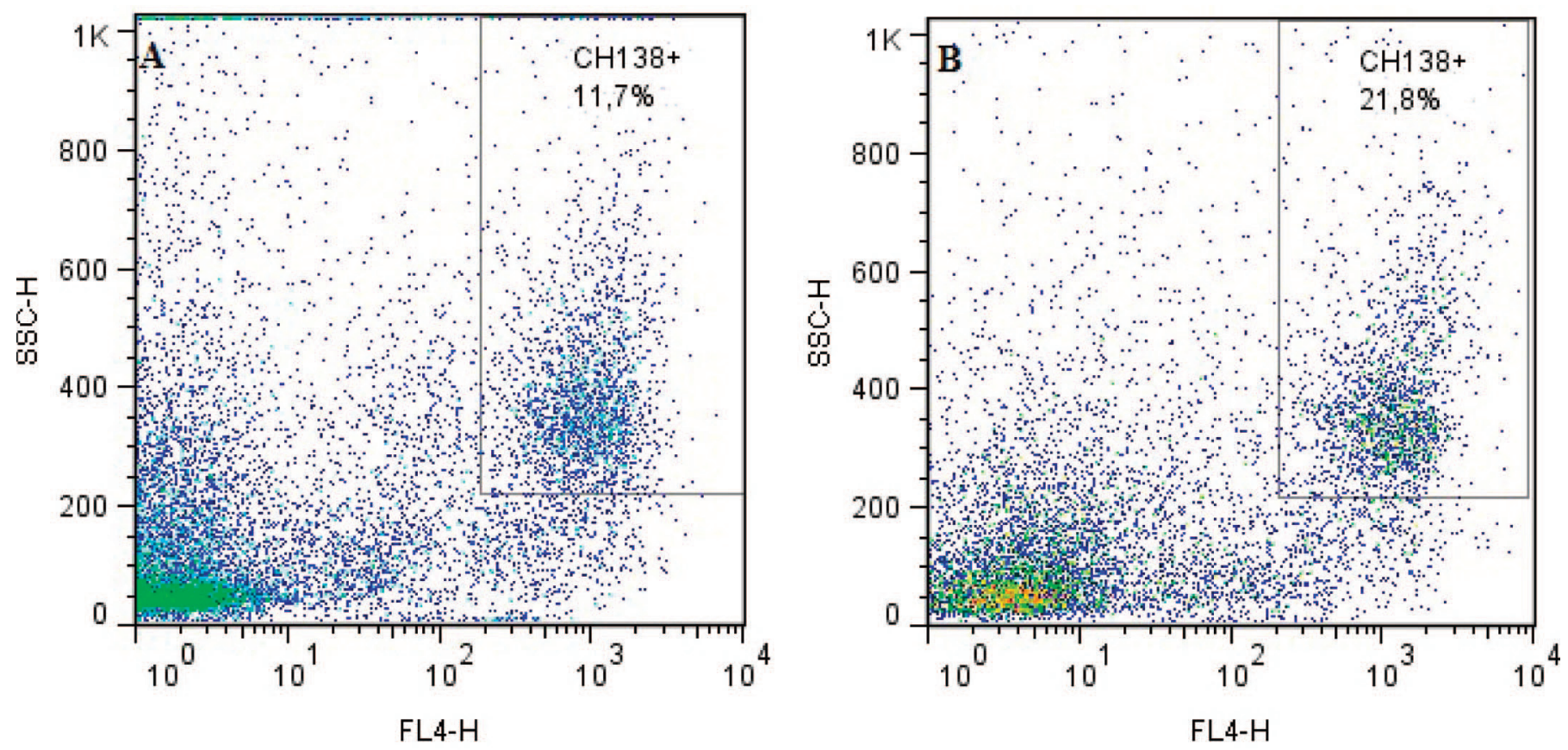

Figure 1. Flow cytometric identification of milk PMNL isolated from (A) uninfected quarters, and (B) quarters infected with Corynebacterium bovis. The recordings of scatter (SSC-H) and fluorescent (FL4-H; CH138A- allophycocyanin) properties were performed with 20,000 events gated on a standard population excluding most cell debris. Color version available in the online PDF.

incubated at room temperature for $20 \mathrm{~min}$ in the dark. Immediately before analysis by flow cytometry, $5 \mu \mathrm{L}$ of $250 \mu \mathrm{g} / \mathrm{mL}$ PI was added. Thereafter, the PMNL were identified using $\mathrm{mAb}$ as described above.

To analyze the data, scatter plots were generated for the gated PMNL. Cells thatwere negative for FITClabeled annexin $\mathrm{V}$ and $\mathrm{PI}$ staining (annexin $\mathrm{V}^{-} / \mathrm{PI}^{-}$) were classified as living and nonapoptotic. Cells that were reactive to FITC-labeled annexin $\mathrm{V}$ but were negative for PI were classified as apoptotic (annexin $\mathrm{V}^{+} / \mathrm{PI}^{-}$; Piepers et al., 2009). Finally, cells that were reactive for both FITC-labeled annexin V and PI were classified as late apoptotic or necrotic (annexin $\mathrm{V}^{+} /$ $\mathrm{PI}^{+}$; Piepers et al., 2009). In total, 20,000 milk cells excluding cellular debris region were examined in each sample. The Flow Jo Tree Star Software (TreeStar Inc., Ashland, OR) was used to analyze the data.

\section{Intracellular Reactive Oxygen Species}

The production of intracellular reactive oxygen species (ROS) was assessed by flow cytometry using 2',7'-dichlorofluorescein diacetate (DCFH-DA) as a probe (Hasui et al., 1989). Briefly, $2 \times 10^{5}$ viable milk cells from each quarter, previously assessed by trypan blue exclusion, were incubated at $37^{\circ} \mathrm{C}$ for 30 min with $0.3 \mu M$ DCFH-DA (D6883, Sigma Aldrich). The intracellular 2',7'-dichlorofluorescein (DCF) fluorescence of the PMNL was determined by flow cytometry using an excitation wavelength of $488 \mathrm{~nm}$. The DCFH-DA (a cell-permeable, nonfluorescent probe) is converted by ROS to DCF in a dose-dependent manner, resulting in fluorescence emission. The green fluorescence from DCF was detected at 500 to $530 \mathrm{~nm}$.

The percentage of the PMNL that produced ROS was calculated as the number of fluorescent PMNL divided by the total PMNL count and multiplied by 100. The median fluorescence intensity of the ROS production was estimated by the geometric median of the DCF fluorescence/PMNL that produced ROS. For this assay, 10,000 gated neutrophils cells were examined in each sample. The Flow Jo Tree Star Software (TreeStar Inc.) was used to analyze the data.

\section{Preparation of PI-Labeled Bacteria}

The preparation of PI-labeled Staphylococcus aureus (ATCC 25923) was performed as proposed by Hasui et al. (1989), with some modifications. Briefly, Staph. aureus was cultured for $18 \mathrm{~h}$ at $37^{\circ} \mathrm{C}$ in brain-heart infusion agar. Subsequently, the bacteria were heat-killed at $60^{\circ} \mathrm{C}$ for $30 \mathrm{~min}$ and washed 3 times in a sterile saline solution $(0.9 \% \mathrm{NaCl})$. The bacterial density was adjusted to an absorbance of 2.50 at $620 \mathrm{~nm}$, and the bacterial density was approximately $2.4 \times 10^{9}$ bacteria/ $\mathrm{mL}$, as previously described (Hasui et al., 1989). The 
bacteria were then labeled with a $5 \%$ solution of PI (P4170, Sigma Aldrich) for $30 \mathrm{~min}$ at room temperature. The fluorescent bacteria were then washed 3 times and suspended in PBS containing $5 \mathrm{~m} M$ glucose and $0.1 \%$ gelatin, and the aliquots were stored at $-80^{\circ} \mathrm{C}$. Thereafter, the PI labeling of the bacteria was confirmed by flow cytometry.

\section{Phagocytosis Assay}

The phagocytosis assay was performed by flow cytometry using PI-labeled Staph. aureus, as previously described by Hasui et al. (1989). Briefly, $2 \times 10^{5}$ viable milk cells were incubated with $100 \mu \mathrm{L}$ of heat-killed, PI-labeled Staph. aureus and $900 \mu \mathrm{L}$ of PBS for 30 min at $37^{\circ} \mathrm{C}$. Subsequently, $2 \mathrm{~mL}$ of $3 \mathrm{~m} M$ EDTA was added; after centrifugation at $400 \times g$ for $10 \mathrm{~min}$, the leukocytes were resuspended in $300 \mu \mathrm{L}$ of PBS and analyzed by flow cytometry.

The percentage of PMNL that phagocytized the bacteria was calculated as the number of fluorescent PMNL divided by the total PMNL count multiplied by 100. The median fluorescence intensity of phagocytosis was estimated by the geometric median of the PI fluorescence/PMNL with phagocytized bacteria. For this assay, 10,000 gated neutrophils cells were examined in each sample. The Flow Jo Tree Star Software (TreeStar Inc.) was used to analyze the data.

\section{Expression of L-Selectin, $\beta_{2}$-Integrin, and CD44}

The identification of PMNL expressing L-selectin (CD62L), $\beta_{2}$-integrin (CD11b), and 1 of the 3 endothelial-selectin (E-selectin) ligands (CD44) was performed by flow cytometry using the following mAb: a FITC-conjugated mouse anti-bovine CD62L antibody (MCA1649F, AbD Serotec, Oxford, UK), a primary mouse IgG1 anti-CD11b mAb (MM12A, Pullman Inc.), a phycoerythrin-Cy5 (PE-Cy5)-conjugated goat antimouse IgG1antibody (M32018, Invitrogen), a primary mouse IgG3 anti-CD44 mAb (BAG40A, Pullman Inc.), and a FITC-conjugated goat anti-mouse IgG3 antibody (M32701, Invitrogen). First, dot plots were gated for PMNL (CH138A), as previously described. The PMNL were first identified as described. Then, the unlabeled primary $\mathrm{mAb}$ for $\mathrm{CD} 11 \mathrm{~b}$ and $\mathrm{CD} 44$ were added to the cell suspension and incubated for $30 \mathrm{~min}$ at room temperature. Afterward, the isolated milk cells suspension was centrifuged at $400 \times g$ for $8 \mathrm{~min}$, and the labeled $\mathrm{mAb}$ CD62L and the secondary labeled $\mathrm{mAb}$ for CD11b and CD44 were added. Finally, the milk isolated cells were incubated for $30 \mathrm{~min}$ at room temperature in the dark to visualize the expression of CD62L, CD11b, and CD44. The expression of L-selectin, $\beta_{2}$-integrin, and CD44 were analyzed in CH138A-positive gated cells. The percentage of the PMNL expressing CD62L, CD11b, and CD44 was calculated as the number of fluorescent PMNL divided by the total PMNL count and multiplied by 100 . The median fluorescence intensity of CD6, CD11b, or CD44 expression was estimated by the geometric median of the fluorescence/PMNL that expressed CD62L, CD11b, or CD44. For this assay, 10,000 gated neutrophils cells were examined in each sample. The Flow Jo Tree Star Software (TreeStar Inc.) was used to analyze the data.

\section{Statistical Analysis}

First, the distribution of all variables was examined through the use of normal probability plots using the Kolmogorov and Smirnov tests (Sampaio, 2010). To compare the differences between the groups, Student's $t$-test for unpaired data was used for the data with normal distributions (the percentage of annexin $\mathrm{V}^{-} / \mathrm{PI}^{+}$ PMNL, the percentage of PMNL that phagocytized Staph. aureus, and the median fluorescence intensity of ROS production and Staph. aureus phagocytosis), and the Mann-Whitney rank test was used for the nonparametric data (the percentage of PMNL, the percentage of annexin $\mathrm{V}^{-} / \mathrm{PI}^{-} \mathrm{PMNL}$, the percentage of annexin $\mathrm{V}^{+} / \mathrm{PI}^{+}$PMNL, the percentage of PMNL that produced ROS, the percentage of PMNL that expressed $\mathrm{CD}_{2} 2 \mathrm{~L}^{+}, \mathrm{CD}_{11} \mathrm{~b}^{+}$, or $\mathrm{CD} 44^{+}$, and the expression of $\mathrm{CD} 62 \mathrm{~L}, \mathrm{CD} 11 \mathrm{~b}$, or CD44). All SCC were $\log _{10}$ transformed, as the distribution was not normal. The statistical analyses were performed using GraphPad Prism 5.0 software (GraphPad Software Inc., San Diego, CA). The results are reported as the means \pm standard errors. The significance was set at $P \leq 0.05$ unless otherwise indicated.

\section{RESULTS}

The results are summarized in Table 1. The logarithmic MSCC was higher in quarters infected with $C$. bovis $(5.38 \pm 0.15)$ than in uninfected $(4.02 \pm 0.12)$ mammary glands $(P<0.0001)$. Furthermore, the percentages of PMNL were higher in the quarters infected with $C$. bovis $(23.52 \pm 3.34 \%)$ than in healthy quarters $(10.31 \pm 2.26 \%, P=0.0012$; Figure 1). We found no differences in the number of days in milk between the C. bovis-infected $(241.5 \pm 22.55)$ and uninfected $(215.9$ $\pm 24.15)$ quarters $(P=0.55)$, suggesting that the differences encountered here were due to IMI.

The results of this study showed higher apoptosis rates (annexin- $\mathrm{V}^{+} / \mathrm{PI}^{-}$) in the PMNL from the uninfected cows $(43.74 \pm 3.82 \%)$ than from the C. bovisinfected cows $(20.05 \pm 1.98 \%, P<0.0001$; Figure 2$)$. 
Table 1. Evaluation of the percentage of milk PMNL and their functions in uninfected $(\mathrm{n}=28)$ and Corynebacterium bovis-infected $(\mathrm{n}=20)$ quarters $^{1}$

\begin{tabular}{lcc}
\hline Item $^{2}$ & Uninfected & Infected \\
\hline SCC & $4.02 \pm 0.12^{\mathrm{b}}$ & $5.38 \pm 0.15^{\mathrm{a}}$ \\
PMNL (\%) & $10.31 \pm 2.26^{\mathrm{b}}$ & $23.52 \pm 3.34^{\mathrm{a}}$ \\
Annexin V $/ \mathrm{PI}^{-}(\%)$ & $43.74 \pm 3.82^{\mathrm{a}}$ & $20.05 \pm 1.98^{\mathrm{b}}$ \\
Annexin V $/ \mathrm{PI}^{+}(\%)$ & $20.33 \pm 2.66^{\mathrm{a}}$ & $18.86 \pm 5.43^{\mathrm{a}}$ \\
Annexin V- $\mathrm{PI}^{-}(\%)$ & $31.07 \pm 3.33^{\mathrm{b}}$ & $51.74 \pm 4.67^{\mathrm{a}}$ \\
CD62L $^{+}(\%)$ & $14.08 \pm 2.09^{\mathrm{a}}$ & $14.18 \pm 3.89^{\mathrm{a}}$ \\
Expression of CD62L & $111.02 \pm 22.58^{\mathrm{a}}$ & $77.85 \pm 19.36^{\mathrm{a}}$ \\
CD11b (\%) & $84.41 \pm 3.03^{\mathrm{a}}$ & $91.07 \pm 3.13^{\mathrm{a}}$ \\
Expression of CD11b & $735.46 \pm 91.19^{\mathrm{a}}$ & $947.80 \pm 112.10^{\mathrm{a}}$ \\
CD44 $(\%)$ & $34.22 \pm 3.65^{\mathrm{a}}$ & $44.62 \pm 6.99^{\mathrm{a}}$ \\
Expression of CD44 & $219.8 \pm 45.98^{\mathrm{a}}$ & $138.9 \pm 30.58^{\mathrm{a}}$ \\
Phagocytosis of Staphylococcus aureus (\%) & $54.54 \pm 3.39^{\mathrm{a}}$ & $54.59 \pm 3.50^{\mathrm{a}}$ \\
Median fluorescence intensity of the phagocytosis of Staph. aureus & $168.9 \pm 15.20^{\mathrm{a}}$ & $136.7 \pm 14.83^{\mathrm{a}}$ \\
Production of ROS (\%) & $65.98 \pm 3.71^{\mathrm{b}}$ & $79.20 \pm 4.79^{\mathrm{a}}$ \\
Median fluorescence intensity of ROS production & $1,419 \pm 131.6^{\mathrm{a}}$ & $1,756 \pm 231.1^{\mathrm{a}}$ \\
\hline
\end{tabular}

$\overline{\mathrm{a}, \mathrm{b}}$ Different superscript letters within a row indicate a significant difference between the values $(P \leq 0.05)$.

${ }^{1}$ The results are shown as mean $\pm \mathrm{SE}$.

${ }^{2} \mathrm{PI}=$ propidium iodide; $\mathrm{ROS}=$ reactive oxygen species .

We found a higher percentage of viable (annexin $\mathrm{V}^{-} /$ $\mathrm{PI}^{-}$) PMNL in the $C$. bovis-infected quarters (51.74 \pm $4.67 \%)$ than in the uninfected quarters $(31.07 \pm 3.33 \%$, $P=0.0006$; Figure 2). No differences were observed in the percentage of annexin $\mathrm{V}^{+} / \mathrm{PI}^{+} \mathrm{PMNL}$ in the $C$. bovis-infected $(18.86 \pm 5.43 \%)$ versus the uninfected $(20.33 \pm 2.66 \%)$ quarters $(P=0.17)$.

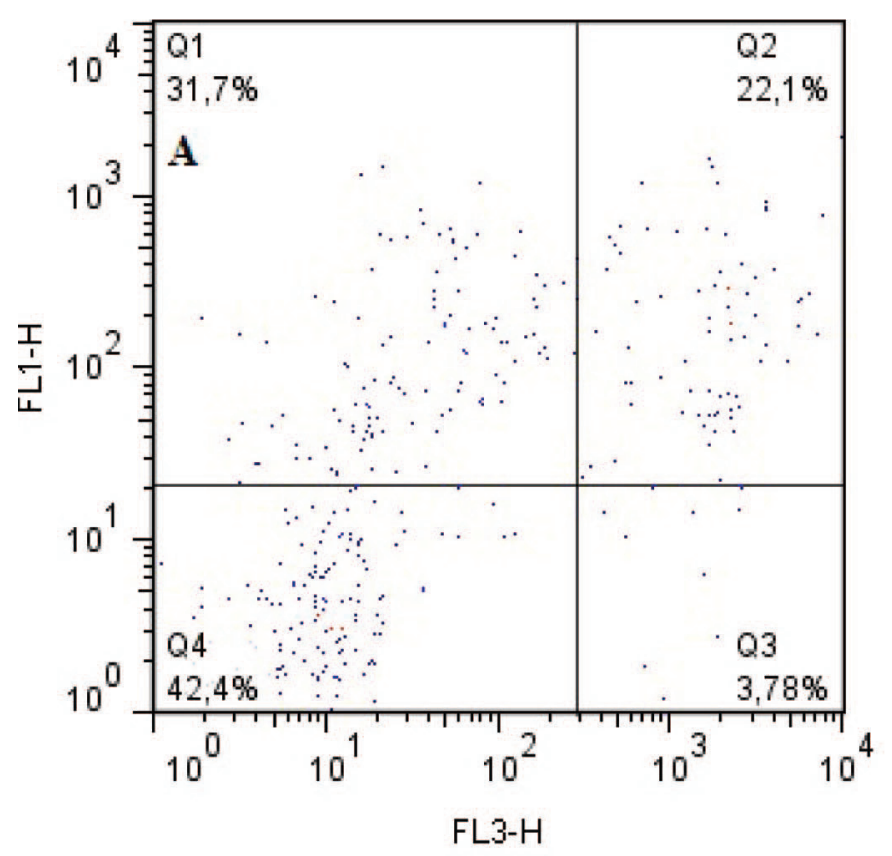

No differences were observed in the percentages of PMNL that phagocytized Staph. aureus in the C. bovisinfected $(54.59 \pm 3.50 \%)$ versus the healthy $(54.54 \pm$ $3.39 \%)$ quarters $(P=0.99)$. Furthermore, no significant differences were observed in the median fluorescence intensity of the Staph. aureus phagocytosis or intracellular ROS production by PMNL between the $C$.

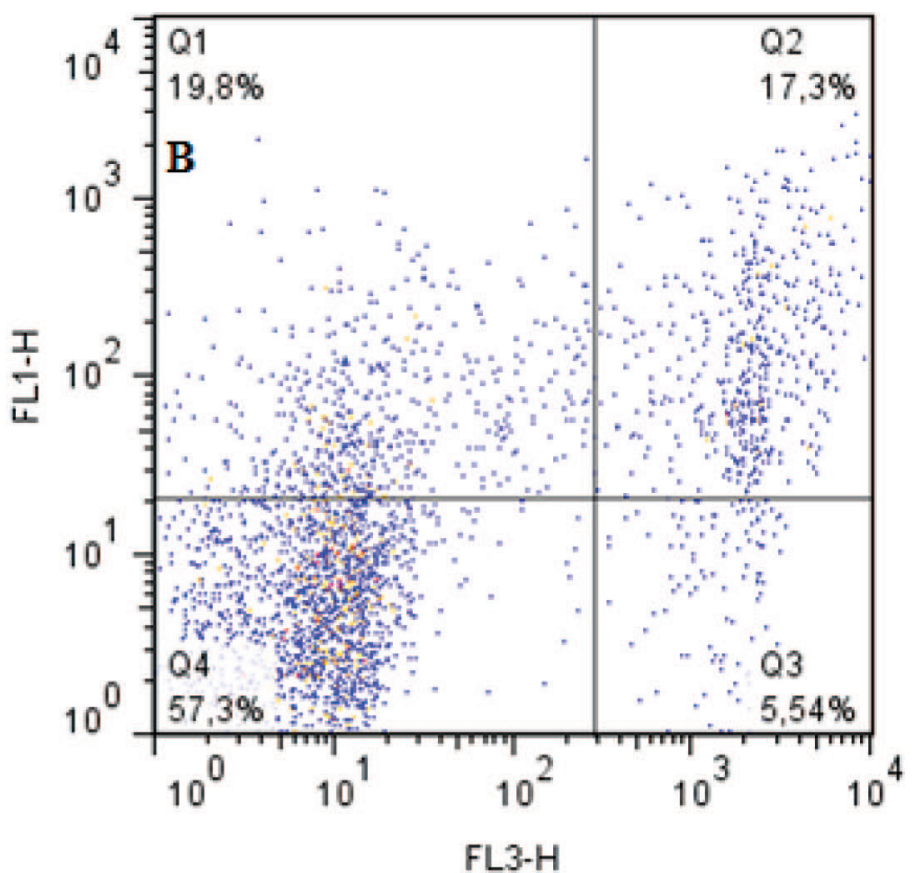

Figure 2. Representative flow cytometric plots of annexin V-fluorescein isothiocyanate (FITC; FL1 axis) versus propidium iodide (PI; FL3 axis). Scatter plot shows the annexin $\mathrm{V}^{+} / \mathrm{PI}^{-}(\mathrm{Q} 1)$, annexin $\mathrm{V}^{+} / \mathrm{PI}^{+}(\mathrm{Q} 2)$, annexin $\mathrm{V}^{-} / \mathrm{PI}^{+}$(Q3), and annexin $\mathrm{V}^{-} / \mathrm{PI}^{-}$(Q4) CH138A-positive events in the milk from (A) uninfected quarters, and (B) quarters infected with Corynebacterium bovis. Color version available in the online PDF. 

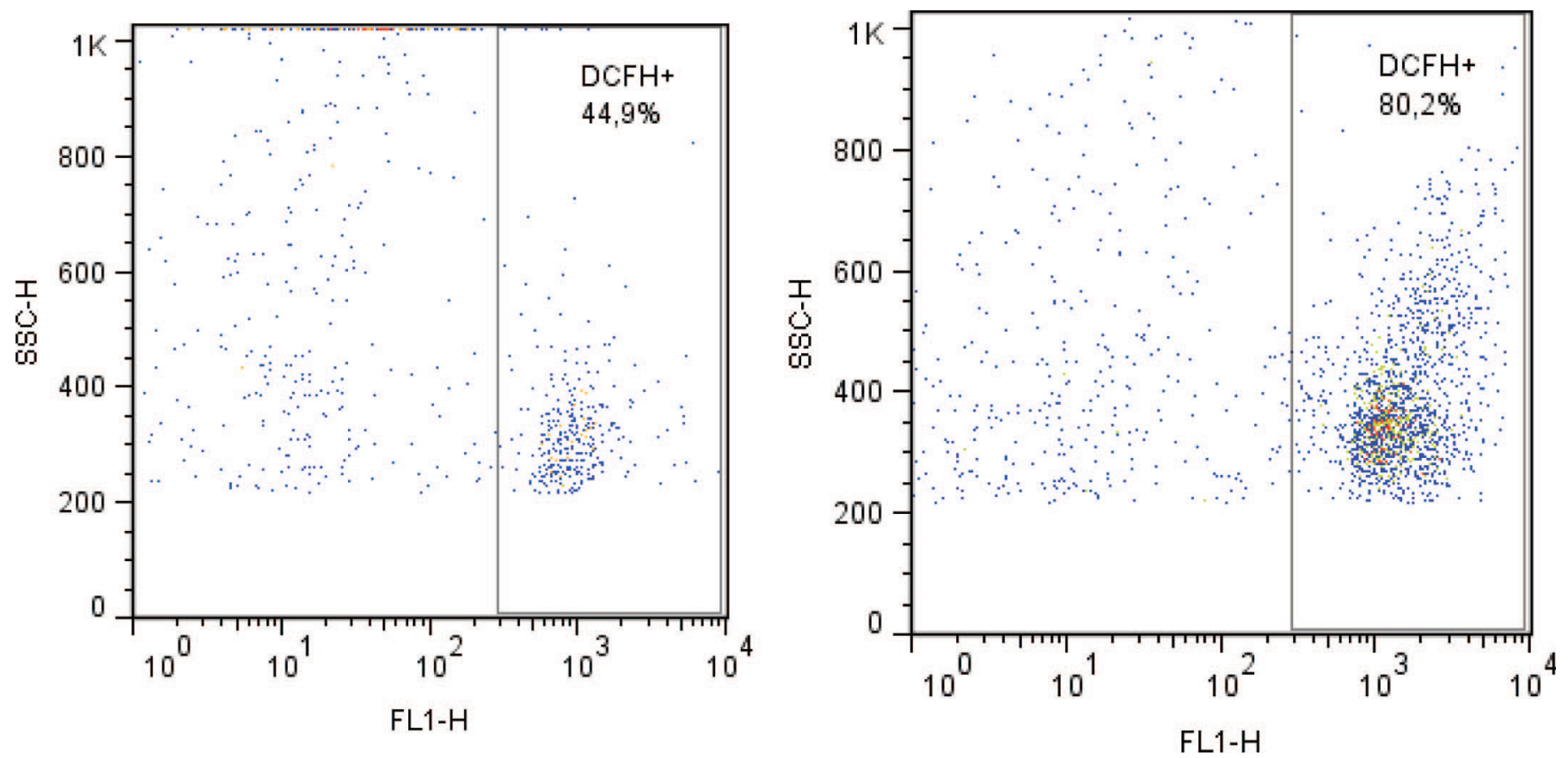

Figure 3. Representative flow cytometric plots of intracellular reactive oxygen species (ROS) production (FL1 axis): percentage of CH138-A positive events indicating the production of intracellular ROS in the milk from (A) uninfected quarters, and (B) quarters infected with Corynebacterium bovis. Color version available in the online PDF. SSC-H $=$ side scatter; DCFH $+=2^{\prime} 7^{\prime}$-dichlorofluorescein positive neutrophils.

bovis-infected (phagocytosis: $136.70 \pm 14.83$; ROS: $1,419 \pm 131.6$ ) and healthy (phagocytosis: $168.9 \pm$ 15.20, $P=0.15$ and ROS: $1,756 \pm 231.1, P=0.18)$ quarters (Figure 3). We also found a higher percentage of PMNL that produced intracellular ROS in the $C$. bovis-infected $(79.20 \pm 4.79)$ versus the healthy $(65.98$ $\pm 3.71)$ quarters $(P=0.0037)$.

The percentage of milk PMNL that expressed L-selectin $(\mathrm{CD} 62 \mathrm{~L})$ in the $C$. bovis-infected quarters (14.18 $\pm 3.89 \%$ ) was not significantly different from that expressed by the PMNL from the healthy quarters (14.08 $\pm 2.09 \% ; P=0.29)$. However, we observed a tendency toward a higher percentage of PMNL that expressed one of the $\alpha$-chains of the $\beta_{2}$-integrin (CD11b) in the C. bovis-infected $(91.07 \pm 3.13 \%)$ versus the uninfected $(84.41 \pm 3.03 \%)$ quarters $(P=0.09)$. No differences were detected between the $C$. bovis-infected and uninfected quarters in expression of L-selectin (77.85 \pm 19.36 vs. $111.02 \pm 22.58 ; P=0.24)$ or $\beta_{2}$-integrin $(947.80 \pm 112.10$ vs. $735.46 \pm 91.19 ; P=0.21)$.

No differences were observed in the percentage of PMNL that expressed CD44 in the C. bovis-infected $(44.62 \pm 6.99 \%)$ compared with the uninfected $(34.22$ $\pm 3.65 \%)$ quarters $(P=0.93)$. No significant difference in CD44 expression by PMNL was found between the $C$. bovis-infected $(138.90 \pm 30.58)$ and uninfected $(219.8 \pm 45.98)$ quarters $(P=0.16)$.

\section{DISCUSSION}

The present study used milk samples from healthy and C. bovis-infected quarters from different cows as well as from the same cows. Given that the immune response against $C$. bovis is primarily localized (Brooks and Barnum, 1984; Huxley et al., 2004) and independent of the quarters, the differences found here might be related to IMI by $C$. bovis. Similarly, some studies that have assessed the immune response in experimentally infected and uninfected quarters of the same cows have demonstrated localization of the immune response to the infected quarters, even in IMI caused by pathogens that lead to a strong immune response characterized by clinical mastitis (Bannerman et al., 2004, 2005).

During mastitis, the inflammatory chemoattractants guide the PMNL toward the foci of the infection. The influx of PMNL from blood to milk in the mammary gland is important for the defense of the mammary gland against bacterial infections (Paape et al., 2003; Rainard and Riollet, 2003, 2006; Zhao and Lacasse, 2008). L-Selectin plays a role in the first step of this egress from the blood flow by facilitating the initial adherence to the endothelium, which is a prerequisite for the endothelial-dependent arrest of the neutrophils. Therefore, L-selectin expression on bovine neutrophils that migrate into tissues is diminished after activation and diapedesis (Diez-Fraille et al., 2004). The $\beta_{2^{-}}$ 
integrins (CD11a, b, c, and CD18) are also important cell surface adhesion molecules involved in the neutrophil migration (Smits et al., 2000; Rainard and Riollet, 2003, 2006). Moreover, CD44 was identified as 1 of the 3 endothelial-selectin (E-selectin) ligands on the PMNL that are responsible for slowing down and stimulating PMNL migration; CD44, in concert with the other 2 E-selectin ligands (ESL-1 and PSGL-1), was required but not essential for PMNL extravasation (PMNL extravasation can occur without expression of CD44) during inflammation (Gonen et al., 2008). The present study found no significant differences in the expression of the cell surface adhesion molecules involved in the PMNL migration evaluated here (CD44, CD62L, and CD11b), in contrast to the higher percentage of milk PMNL in C. bovis-infected quarters. However, we did observe a tendency toward a higher percentage of milk PMNL that expressed one of the $\alpha$-chains of $\beta_{2}$-integrin (CD11b) in C. bovis-infected quarters.

The persistent accumulation of inflammatory cells at the site of infection requires both continuous neutrophil influx and increased survival of the extravasated neutrophils (Boutet et al., 2004). The present study encountered lower percentages of apoptotic PMNL and higher levels of PMNL viability in C. bovis-infected quarters. Thus, this finding agrees with those of Boutet et al. (2004), who described a delayed neutrophil apoptosis program during subclinical bovine mastitis. The enhanced neutrophil survival in the milk of subclinical mastitis-affected cows is due at least in part to the role of the granulocyte-macrophage colony-stimulating factor (GM-CSF)-activated STAT5 signaling pathway (Boutet et al., 2004), and GM-CSF expression is augmented in the milk cells of mastitis-affected cows (Boulanger et al., 2003).

Neutrophils are essential for the innate host defense against invading microorganisms, and they eliminate pathogens through phagocytosis. During phagocytosis, PMNL release ROS into the pathogen-containing vacuoles to kill the invading pathogens (Paape et al., 2003; Rainard and Riollet, 2006). The PMNL are the first line of defense against infection, and the active stage of immune defense requires the presence of viable and immunocompetent cells (Baumert et al., 2009). In the present study, a higher percentage of PMNL viability and a higher percentage of PMNL that produced intracellular ROS were identified in the $C$. bovis-infected quarters. In fact, the viability of PMNL and their capacity to produce ROS are inextricably connected (Mehrzad et al., 2004). In light of this, the results from this study evaluating PMNL quantity and function support, at least in part, the idea that IMI by $C$. bovis can provide protection against IMI caused by other pathogenic bacteria, especially considering that the presence of preexisting milk PMNL and boosting the viability of milk PMNL are involved in the underlying mechanism of the udder's innate defense against bacteria (Mehrzad et al., 2004, 2005). No significant difference in phagocytosis activity was observed here, which may be related to the high number of bacteria:cells $(1: 1,200)$ used in the present study.

Thus, our data are in agreement with other studies that found a significant association between the presence of IMI by $C$. bovis and a reduction in the occurrence of new IMI caused by other pathogenic bacteria (Brooks and Barnum, 1984; Pankey et al., 1985; Sordillo et al., 1988; Lam et al., 1997; Schukken et al., 1999), although no consensus was found (Rainard and Poutrel, 1982; Brooks et al., 1983; Honkanen-Buzalski et al., 1984; Zadoks et al., 2001; Reyher et al., 2012). Besides our data regarding PMNL function, other explanations may be related to competitive growth inhibition, bacterial antagonism, or enhancement of the immunoglobulinproducing plasma cells in both the parenchymal and teat-end tissues of C. bovis-infected quarters (Brooks and Barnum, 1984; Sordillo et al., 1988).

\section{ACKNOWLEDGMENTS}

The authors are grateful for the financial support from the São Paulo State Research Foundation (FAPESP Project no. 2009/50672-0).

\section{REFERENCES}

Bannerman, D. D., A. Chockalingam, M. J. Paape, and J. C. Hope 2005. The bovine innate immune response during experimentallyinduced Pseudomonas aeruginosa mastitis. Vet. Immunol. Immunopathol. 107:201-215.

Bannerman, D. D., M. J. Paape, W. R. Hare, and J. C. Hope. 2004. Characterization of the bovine innate immune response to intramammary infection with Klebsiella pneumoniae. J. Dairy Sci. $87: 2420-2432$.

Bansal, B. K., J. Hamann, N. T. Grabowskit, and B. Singh. 2005. Variation in the composition of selected milk fraction samples from healthy and mastitic quarters, and its significance for mastitis diagnosis. J. Dairy Res. 72:144-152.

Baumert, A., R. M. Bruckmaier, and O. Wellnitz. 2009. Cell population, viability, and some key immunomodulatory molecules in different milk somatic cell samples in dairy cows. J. Dairy Res. 76:356-364.

Benites, N. R., P. A. Melville, and E. O. Costa. 2003. Evaluation of the microbiological status of milk and various structures in mammary glands of from naturally infected dairy cows. Trop. Anim. Health Prod. 35:301-307.

Boulanger, D., F. Bureau, D. Mélotte, J. Mainil, and P. Leukeux. 2003. Increased nuclear factor $\kappa \mathrm{B}$ activity in milk cells of mastitisaffected cows. J. Dairy Sci. 86:1259-1267.

Boutet, P., D. Boulanger, L. Gillet, A. Vanderplasschen, R. Closset, F. Bureau, and P. Lekeux. 2004. Delayed neutrophil apoptosis in bovine subclinical mastitis. J. Dairy Sci. 87:4104-4114.

Brooks, B. W., and D. A. Barnum. 1984. The susceptibility of bovine udder quarters colonized with Corynebacterium bovis to experimental infection with Staphylococcus aureus or Streptococcus agalactiae. Can. J. Comp. Med. 48:146-150. 
Brooks, B. W., D. A. Barnum, and A. H. Meek. 1983. An observational study of Corynebacterium bovis in selected Ontario dairy herds. Can. J. Comp. Med. 47:73-78.

Diez-Fraille, A., J. Mehrzad, E. Meyer, L. Duchateau, and C. Burvenich. 2004. Comparison of L-selectin and Mac-1 expression on blood and milk neutrophils during experimental Escherichia coli-induced mastitis in cows. Am. J. Vet. Res. 65:1164-1171.

Djabri, B., N. Bareille, F. Beaudeau, and H. Seegers. 2002. Quarter milk somatic cell count in infected dairy cows: A meta-analysis. Vet. Res. 33:335-357.

Elazar, S., E. Gonen, A. Livneh-Kol, I. Rosenshine, and N. Y. Sphigel. 2010. Essential role of neutrophils but not mammary alveolar macrophages in a murine model of acute Escherichia coli mastitis. Vet. Res. 41:53.

Gonen, E., S. Nedvtzki, D. Naor, and N. Y. Shpigel. 2008. CD44 is highly expressed on milk neutrophils in bovine mastitis and plays a role in their adhesion to matrix and mammary epithelium. Vet. Res. 39:29.

Haltia, L., T. Honkanen-buzalski, I. Spiridonova, A. Olkonen, and V. Myllys. 2006. A study of bovine mastitis, milking procedures and management practices on 25 Estonian dairy herds. Acta Vet. Scand. 48:22.

Hasui, M., Y. Hirabayashi, and Y. Kobayashi. 1989. Simultaneous measurement by flow cytometry of phagocytosis and hydrogen peroxide production of neutrophils in while blood. J. Immunol. Methods 117:53-58.

Hogan, J. S., K. L. Smith, D. A. Todhunter, and P. S. Schoenberger. 1988. Rate of environmental mastitis in quarters infected with Corynebacterium bovis and Staphylococcus species. J. Dairy Sci. $71: 2520-2525$.

Honkanen-Buzalski, T., T. K. Griffin, and F. H. Dood. 1984. Observations on Corynebacterium bovis infection of the bovine mammary gland. I. Natural infection. J. Dairy Res. 51:371-378.

Huxley, J. N., C. R. Helps, and A. J. Bradley. 2004. Identification of Corynebacterium bovis by endonuclease restriction analysis of the 16S rRNA gene sequence. J. Dairy Sci. 87:38-45.

Koess, C., and J. Hamann. 2008. Detection of mastitis in the bovine mammary gland by flow cytometry at early stages. J. Dairy Res. $75: 225-232$.

Lam, T. J., Y. H. Schukken, J. H. van Vliet, F. J. Grommers, M. J. Tielen, and A. Brand. 1997. Effect of natural infection with minor pathogens on susceptibility to natural infection with major pathogens in the bovine mammary gland. Am. J. Vet. Res. 58:17-22.

Mehrzad, J., L. Duchateau, and C. Burvenich. 2004. Viability of milk neutrophils and severity of bovine coliform mastitis. J. Dairy Sci. 87:4150-4162.

Mehrzad, J., L. Duchateau, and C. Burvenich. 2005. High milk neutrophil chemiluminescence limits the severity of bovine coliform mastitis. Vet. Res. 36:101-116.

Oliver, S. P., R. N. González, J. S. Hogan, B. M. Jayarao, and W. E. Owens. 2004. Microbiological Procedures for the Diagnosis of Bovine Udder Infection and Determination of Milk Quality. National Mastitis Council, Verona, WI.

Paape, M. J., D. D. Bannerman, X. Zhao, and J. W. Lee. 2003. The bovine neutrophil: Structure and function in blood and milk. Vet. Res. 34:597-627.

Pankey, J. W., N. C. Nickerson, R. L. Boddie, and J. S. Hogan. 1985. Effects of Corynebacterium bovis infection on susceptibility to major pathogens. J. Dairy Sci. 68:2684-2693.

Piepers, S., S. De Vliegher, K. Demeyere, B. N. Lamrecht, A. Kruif, E. Meyer, and G. Opsomer. 2009. Technical note: Flow cytometric identification of bovine milk neutrophils and simultaneous quantification of their viability. J. Dairy Sci. 92:626-631.
Pitkälä, A., M. Haveri, S. Pyörälä, V. Myllys, and T. Honkanen-Buzalski. 2004. Bovine mastitis in Finland 2001-Prevalence, distribution of bacteria, and antimicrobial resistance. J. Dairy Sci. $87: 2433-2441$

Rainard, P., and B. Poutrel. 1982. Dynamics of nonclinical bovine intramammary infections with major and minor pathogens. Am. J. Vet. Res. 43:2143-2146.

Rainard, P., and B. Poutrel. 1988. Effect of naturally occurring intramammary infections by minor pathogens on new infections by major pathogens in cattle. Am. J. Vet. Res. 49:327-329.

Rainard, P., and C. Riollet. 2003. Mobilization of neutrophils and defense of the bovine mammary gland. Reprod. Nutr. Dev. 43:439457.

Rainard, P., and C. Riollet. 2006. Innate immunity of the bovine mammary gland. Vet. Res. 37:369-400.

Reyher, K. K., I. R. Dohoo, D. T. Scholl, and G. P. Keefe. 2012. Evaluation of minor pathogens intramammary infection, susceptibility parameters, and somatic cell counts on the development of new intramammary infections with major mastitis pathogens. J. Dairy Sci. 95:3766-3780.

Sampaio, I. B. M. 2010. Estatística Aplicada à Experimentação Animal. 3rd ed. Editora Fundação de Ensino e Pesquisa em Medicina Veterinária e Zootecnia. Escola de Veterinária, Belo Horizonte, MG, Brazil.

Schukken, Y. H., K. E. Leslie, D. A. Barnum, B. A. Mallard, J. H. Lumsden, P. C. Dick, G. H. Vessie, and M. E. Kehrli. 1999. Experimental Staphylococcus aureus intramammary challenge in late lactation dairy cows: Quarter and cow effects determining the probability of infection. J. Dairy Sci. 82:2393-2401.

Schwarz, D., U. S. Diesterbeck, K. Failing, S. König, K. Brügemann, M. Zschöck, W. Wolter, and C. P. Czerny. 2010. Somatic cell counts and bacteriological status in quarter foremilk samples of cows in Hesse, Germany-A longitudinal study. J. Dairy Sci 93:5716-5728.

Smits, E., C. Burvenich, A. J. Guidry, and A. Massart-Leën. 2000. Adhesion receptor CD11b/CD18 contributes to neutrophil diapedesis across the bovine blood-milk barrier. Vet. Immunol. Immunopathol. 73:255-265.

Sordillo, L. M., S. P. Oliver, A. J. Guidry, and J. T. Dermody. 1988 Humoral immune response of bovine mammary glands colonized with Corynebacterium bovis: Enumeration of plasma cell populations in tissue and immunoglobulin concentrations in milk. Zentralbl. Veterinarmed. B 35:617-627.

Souza, G. N., J. R. F. Brito, E. C. Moreira, M. A. V. P. Brito, and M. V. G. B. Silva. 2009. Variação da contagem de células somáticas em vacas leiteiras de acordo com patógenos da mastite. Arq. Bras. Med. Vet. Zoot. 61:1015-1020.

Tenhagen, B. A., G. Köster, J. Wallmann, and W. Heuwieser. 2006. Prevalence of mastitis pathogens and their resistance against antimicrobial agents in dairy cows in Brandenburg, Germany. J. Dairy Sci. 89:2542-2551

Wilson, D. J., R. N. Gonzalez, and H. H. Das. 1997. Bovine mastitis pathogens in the New York and Pennsylvania: Prevalence and effects on somatic cell count and milk production. J. Dairy Sci. 80:2592-2598

Zadoks, R. N., H. G. Allore, H. W. Barkema, O. C. Sampimon, G. J. Wellenberg, Y. T. Gröhn, and Y. H. Schukken. 2001. Cow- and quarter-level risk factors for Streptococcus uberis and Staphylococcus aureus mastitis. J. Dairy Sci. 84:2649-2663.

Zhao, X., and P. Lacasse. 2008. Mammary tissue damage during bovine mastitis: Causes and control. J. Anim. Sci. 86:57-65. 